\title{
Preventing and Controlling Pneumonia among Under-Five Children: A Qualitative Study of Civil Society Organizations' Roles in West Java and East Nusa Tenggara
}

\author{
Habsyah Saparidah Agustina ${ }^{1 *}$ (D), Restuning Widiasih² ${ }^{2}$, Binahayati Rusyidi ${ }^{3} \mathbb{D}$, Nenden Nur Asriyani Maryam $^{4}$ (D) \\ ${ }^{1}$ Department of Mental Health Nursing, Faculty of Nursing, Universitas Padjadjaran, Bandung, Indonesia; ${ }^{2}$ Department of \\ Maternity Nursing, Faculty of Nursing, Universitas Padjadjaran, Bandung, Indonesia; ${ }^{3}$ Department of Social Welfare, Faculty \\ of Social and Political Science, Universitas Padjadjaran, Bandung, Indonesia; ${ }^{4}$ Department of Pediatric Nursing, Faculty of \\ Nursing, Universitas Padjadjaran, Bandung, Indonesia
}

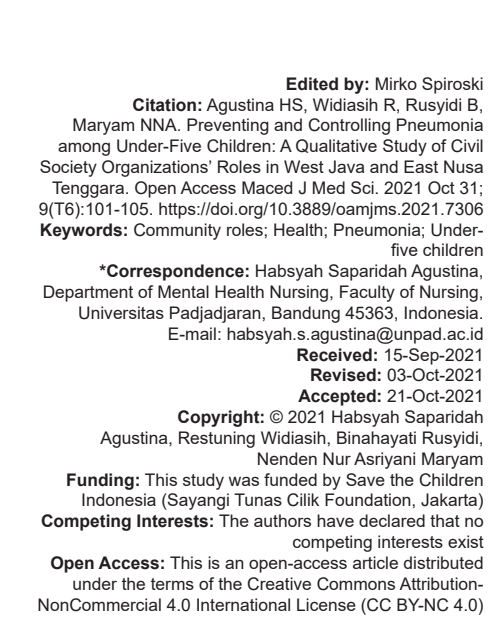

\section{Abstract}

BACKGROUND: Pneumonia is the leading cause of under-five children mortality in the world, including in Indonesia. Various programs were developed both nationally and internationally to overcome this disease. One of the programs is cross-sectorial collaboration and community involvement as part of pneumonia prevention and control programs, including the involvement of civil society organizations (CSO). However, the limited research has explored through the role of CSO in this program.

AIM: This study aimed to explore the roles of CSO in preventing and controlling the childhood pneumonia.

METHODS: This qualitative descriptive study interviewed 15 participants who were representatives of CSO in West Java and East Nusa Tenggara. These CSO have focused on health activities programs. In-depth interviews were conducted using semi-structured interview guides. Data were analyzed using the comparative analysis technique for qualitative descriptive research.

RESULTS: Three main themes have been found from the data analysis, including community empowerment and integrated actions to prevent childhood pneumonia, providing pneumonia services and advocacies to overcome childhood pneumonia, and the expectation versus challenges of CSO. The three themes showed that CSO have significant roles in various aspects of the prevention and control programs of under-five pneumonia.

CONCLUSION: Various roles have been done by CSO. However, several functions were not performed optimally. Further research that was analyzing factors the influence CSO's roles is needed as fundamental information to develop strategies in improving the functions of civil society organizations in childhood pneumonia.

\section{Introduction}

Pneumonia in children is indicated by the World Health Organization (WHO) as the leading cause of death for children under five [1]. This disease is mainly developed by children in developing countries in Africa and Asia, including Indonesia [1]. Pneumonia in Indonesia is also the second biggest cause of child death after diarrhea. In 2018, an estimated 19,000 children died from pneumonia in Indonesia, and in general, it is estimated that every hour, there are 71 children infected with pneumonia [2].

Pneumonia in children is the concern of various $\mathrm{WHO}$, such as the WHO, UNICEF, and Save the Children. These organizations are developing new pneumonia in children based on efforts to prevent, protect, and treat [3], [4], [5]. The same is done in Indonesia; since 1984, the Ministry of Health of the Republic of Indonesia has developed programs that focus on promoting, preventing, and improving family-based management of pneumonia (diagnosis and treatment) [6]. Besides, based on the WHO guidelines, the government has also developed a guide for Integrated Management of Children with IIIness which the Ministry of Health has published as new management for childhood pneumonia in Indonesia [7].

Prevention efforts have been made, but the prevalence of pneumonia remains high in Indonesia; 20 out of 34 provinces are identified as having a higher prevalence than the national average prevalence. These conditions may occur due to various factors, including low coverage of exclusive breastfeeding, environmental conditions, other diseases suffered by children, parenting, socio-cultural conditions, and knowledge of anemia [8].

A collaborative, multisectoral, and interprofessional approach is vital for treating pediatric pneumonia. The guidebook for the Prevention and Control of Pneumonia, published by the P2PM Ministry of Health [6], clearly explains the role of each element 
of health, including the role of Community Social Institutions (NGOs) or also known as Civil Society Organizations (CSOs).

CSOs are a non-state, not-for-profit, and voluntary organization that can influence and mobilize positive potential in the community. CSOs in health's role are advocacy, participating, and collaborating with government and society in the health system [9]. The role of CSOs in health development has been scrutinized in various countries [9], [10], [11], [12], [13], [14]. Research has been carried out related to advocacy, decisionmaking, and implementing health programs in diseases such as HIV and children's health. Although there are many health activities and programs that CSOs have developed, there are still few studies on the role of CSOs in the health sector, especially children with pneumonia in Indonesia. This study aimed to explore in-depth the role of CSOs in preventing and controlling pneumonia in toddlers.

\section{Methods}

\section{The research team and reflexivity}

The research team in this study was four people. Each researcher has their respective roles and duties. All researchers' reflexivity in reference to this qualitative research is due to the fact that pneumonia is the top cause of death in children under the age of five worldwide, including in Indonesia. Various programs were developed both nationally and internationally to overcome this disease. One of the programs is crosssectorial collaboration and community involvement as part of pneumonia prevention and control programs, including involvement (CSOs).

\section{Study design}

This research design uses a qualitative descriptive approach. This approach is suitable for exploring things or activities that are still being done today. This naturalistic technique is frequently used in nursing and healthcare to investigate pressing topics and to offer a full, descriptive account of participants' experiences to influence practice and service delivery [15]. The data were collected using the in-depth interview method using the interview semistructured guide. The interview guide has been tested before use. The aspects explored in the interview included: (a) The role of institutions in the Indonesian health system, (b) perceptions of child pneumonia in Indonesia and its regions, (c) the importance of the pneumonia program, (d) the pneumonia program for prevention and overcoming disease, (e) program achievement, (f) program budget, (g) supporting and inhibiting factors, as well as challenges in program implementation, and (h) efforts and plans to overcome obstacles and challenges.

\section{Sample and setting}

Participants in this study were CSOs who have health programs, especially children's health; 15 informants with a background in implementing health programs from CSOs participated in this study. The research was conducted in East Nusa Tenggara Province as the province with the highest prevalence of pneumonia in Indonesia and West Java Province, which has a prevalence of pneumonia equal to the national average.

\section{Data collection}

The steps for collecting qualitative data included applying for permission to research, piloting interviews with two CSO activists in West Java, and providing research explanations to participants. Furthermore, it determines a schedule for the time and place for the interview. Individual interviews, starting with providing information about the research, asking for approval, completed a consent form, followed by a 30-60 min interview and recorded.

\section{Data analysis}

The qualitative data analysis used the comparative analysis method. The study includes four main steps: The coding preparation stage, which consists of reading the transcript and creating a resume to understand the data's contents. Then, proceed with coding using software, formulating themes, and integrating the results. The coding process in this analysis uses the NVivo 10 software program. The researcher determines the theme of the data in each source. This research's final stage is triangulation, integrating themes from CSO NTT and West Java data sources to get a broader picture.

\section{Ethical clearance}

This research has obtained ethical approval from the Research Ethics Committee of Padjadjaran University number 797/UN6.KEP/EC/2018.

\section{Results}

Based on data analysis results, there are three themes: Community empowerment and integrated action to prevent toddler pneumonia, health service providers and advocacy for under-five pneumonia 
prevention efforts, and expectations versus challenges of CSOs related to toddler pneumonia.

\section{Theme 1: Community empowerment and} integrated action to prevent toddler pneumonia

The analysis results show that CSOs in West Java and NTT play a role in supporting pneumonia prevention programs through community empowerment and various integrated pneumonia prevention programs. Integrated into this article is pneumonia prevention carried out in collaboration with other parties and different activities.

Partnerships are carried out with various parties such as health workers, cadres, communities, other CSOs, schools, and of course with the government, especially local governments. NTT CSOs such as Save the Children and the Sumba Foundation play an active role in preventing pneumonia and other diseases such as malaria. CSOs in West Java have also done the same thing; efforts to prevent children's disease are part of CSO programs such as GIZ, PKBI, and AIMI. They are related to overcoming pneumonia risk factors.

"Yes, we have several collaborations with hospitals and clinics in each province, there must be cooperation, whether it is in the form of socialization or whether we are then in the form of we also provide counseling for patients there, in essence, we also help the hospital if, for example, we want to implement 10 LKM. That is how they are; for example, there is a breastfeeding counselor in the hospital, right? Maybe there is not one, so we can help. The baby's health level will definitely increase the health level because all the research results show that babies who get exclusive breastfeeding and continue to have immunity are much higher than those who do not get breast milk. The longer he gets breast milk, the higher the health level."

CSOs working in the health and social sector have an awareness of the community's health problems, including toddler pneumonia. They develop programs with clear targets every year, make maximum efforts, innovations, and creations to achieve these targets. The many roles and potentials of CSOs will help support healthy development in Indonesia, including children's health, particularly the prevention of pneumonia.

\section{Theme 2: Providing pneumonia services and advocacies to overcome childhood pneumonia}

The interview results obtained information that several CSOs provide direct health services for the community for free, including pneumonia such as the Sumba Foundation, which focuses on health services for malaria. Still, even if there are pneumonia patients, they are served. In Bandung Regency, there is a Sinergy Foundation that provides free delivery and includes child health services:

"Quite often, the patient is a child with pneumonia, but usually it is the seasonal season, yes. There are times when I do not find it. For example, you can find, for example, five patients have been there in a day; two or five may also be seen from the season. So if the season is not good, it tends to be humid. Usually, it causes pneumonia."

Advocacy in the form of strengthening health budgets, including children's health, has been carried out by several CSOs, including the Bahtera Foundation, and the initiative for enhancing the implementation of health programs related to toddler pneumonia and advocacy carried out by CSOs is a picture of their real role as part of Indonesian society in the effort to tackle toddler pneumonia.

\section{Theme 3: The expectations versus challenges of CSOs relating to toddler pneumonia}

The analysis results obtained information on the various expectations of CSOs in partnership with the government and the challenges faced when carrying out health programs, especially child pneumonia. The hope of good cooperation between CSOs and the government can be increased concerning children's health, especially the prevention and control of pneumonia:

"With the free services we provide, training 1000 cadres, helping families, and children who cannot afford the process of treatment, referrals, hopefully, we can partner well with the government."

The challenges faced by CSOs in carrying out their programs and roles, CSOs face various problems, including community behavior, limited human resources in CSOs with a background in health education, and continuity of funding. One of the CSOs that focus on maternal and child health conveyed that many Indonesians, especially in West Java, still do not realize the importance of maintaining children's health through preventive measures such as late immunization and breastfeeding. Apart from that, they are also dealing with economic problems.

"But the point is that in Indonesia there are still a lot of poor people in Bandung, so we still have a lot to help because if, for example, he is poor, he cannot be repaired, of course, in terms of health, it is also difficult because his condition is not suitable for his house, the food is a slum. Nutritious if we want to get a good degree of health."

The hopes and challenges of CSOs are faced with a high commitment to participate in health development in Indonesia, especially children's health and childhood health. 


\section{Discussion}

The results of the analysis get three main themes that explain the various roles of CSOs in the prevention and control of toddler pneumonia, including community empowerment through cadre training, collaborating with the health office and health services, advocating for various programs, budgets, and policies related to child health, including pneumonia toddler. The role of CSOs related to pneumonia in children is written in the guidebook for prevention and control of pneumonia published by the P2PM of the Ministry of Health, explaining the roles of each element of health in the prevention and control of pneumonia, including the role of CSOs.

The roles of CSOs in the guidelines published by the Ministry of Health of the Republic of Indonesia [6] that have not been carried out or have not been maximized are related to helping the prevention of an influenza pandemic epicenter, developing guidelines for ARI control and prevention, establishing national policies for pneumonia control, facilitating the establishment of posts and pandemic preparedness influenza, and epicenter preparedness [6]. Some of the roles listed in the guidebook are not specific to cases of childhood pneumonia. Still, based on data analysis, most have been implemented for roles related to pneumonia, but some aspects are not yet optimal. CSOs follow government regulations to open clinics and provide assistance, including cases of childhood pneumonia. The role of CSOs, which has not been maximized, can be maximized with more structured coordination between CSOs and the government with clear technical guidelines because basically, CSOs have great potential to support the improvement of public health, including the health of toddler's pneumonia.

The role of CSOs in health has been widely studied in various countries, both at the regional level and the health system level of a country, for many years [14], [16], [17], [18], [19], [20]. The previous studies included the role of CSOs concerning mental health, advocacy, social health issues, and tobacco problems. The roles of CSOs that have been carried out in the two provinces are in line with the analysis of the roles of CSOs that have been carried out. This study adds new information and knowledge about the role of CSOs, especially toddler pneumonia, because there is limited research on the role of CSOs concerning these diseases, including in Indonesia.

The role of CSOs in the health system related to toddler pneumonia in this study is to carry out advocacy and strengthen the pneumonia program that the Government of Indonesia has developed through the Ministry of Health. The role of advocacy is one of the main messages of CSOs, and this is corroborated by research in Canada [18], Australia [19], and The Caribbean region [21], which results in an overview of advocacy carried out by CSOs for smoking policies and ethnic diversity, although this research is not specific to pneumonia, described the role of advocacy and program strengthening is a significant role of CSOs for improving public health, including in child health: Pneumonia toddler. Health advocacy includes a combination of social or individual activities designed to increase political commitment, health policy support, and social acceptance to a health program's success.

\section{Conclusion}

Therefore, it can be concluded that CSOs have played various roles to support health development in Indonesia, especially the prevention and control of toddler pneumonia. Hope and challenges have been identified in this research. Some of the roles of CSOs have not been applied yet; maximizing the role of CSOs following the guidelines for prevention and control of pneumonia can improve the health of toddlers and reduce these health problems. Therefore, further research is needed on the factors that influence the role of CSOs in a qualitative and quantitative study as information to develop strategies for increasing the role of CSOs in toddler pneumonia. In addition, during the research process, the researcher did not have any limitations.

\section{References}

1. World Health Organization. Pneumonia New York: World Health Organization; 2019. https://doi. org/10.4324/9780203029732-9

2. UNICEF. One Child Dies of Pneumonia Every 39 Seconds, Agencies Warn London: UNICEF Indonesia. New York: UNICEF; 2019. https://doi.org/10.1163/2210-7975_hrd-9841-20180003

3. Save the Children, Fighting for Breath. Science. 2002;295(5563):2173n-3. https://doi.org/10.1126/ science.295.5563.2173n

4. World Health Organization. GAPPD: Ending Preventable Child Deaths from Pneumonia and Diarrhoea by 2025 . New York: World Health Organization; 2013. https://doi. org/10.1163/2210-7975_hrd-9841-3003

5. UNICEF. One is Too Many: Ending Child Deaths from Pneumonia and Diarrhoea. New York: UNICEF; 2016. https://doi. org/10.1163/2210-7975 hrd-9841-3003

6. Kementrian Kesehatan Republik Indonesia. Revisi Buku Pedoman Pencegahan dan Pengendalian Infeksi Saluran Pernapasan Akut (ISPA). Jakarta: Kementrian Kesehatan Republik Indonesia; 2016. https://doi.org/10.6066/ jtip.2013.24.2.121

7. Kementrian Kesehatan Republik Indonesia. Buku Panduan Manjemen Terpadu Balita Sakit. Jakarta: Kementrian Kesehatan Republik Indonesia; 2018. https://doi.org/10.6066/ jtip.2013.24.2.121 
8. Widiasih R, Douren E. Analisis Situasi Pneumonia pada Anak: Kebijakan di Aras Nasional dan Implementasi Penanganan di Kabupaten Bandung dan Sumba Barat, Indonesia. Jakarta: Ringkasan Eksekutif; 2019. https://doi.org/10.31983/link. v15i2.4790

9. Greer SL, Wismar M, Kosinska M. What is civil society and what can it do for health? In: Greer SL, Wismar M, Pastorino G, Kosinska M, editors. Civil Society and Health Contributions and Potential. United States: Copenhagen WHO Europe Regulation Office; 2017. p. 3-25. https://doi.org/10.1093/eurpub/ ckw173.054

10. Choy R, Duke T. The role of non-government organizations in supporting and integrating interventions to improve child health. P N G Med J. 2000;43(1-2):76-81.

11. Gómez EJ. Civil society in global health policymaking: A critical review. Global Health. 2018;14(1):73.

12. Kankya C, Akandinda A, Rwabukwali CB. The role of civil society organisations (CSOs) in healthcare delivery system: A case study of child immunisation in Kabarole district, Uganda. Health (Irvine Calif). 2013;5(8):1277-88. https://doi.org/10.4236/ health.2013.58174

13. Storeng $\mathrm{KT}$, de Bengy Puyvallée A. Civil society participation in global public private partnerships for health. Health Policy Plan. 2018;33(8):928-36. https://doi.org/10.1093/heapol/czy070 PMid:30165606

14. Piotrowicz M, Cianciara D. The role of non-governmental organizations in the social and the health system. Przegl. Epidemiol. 2013;67(1):69-74.

PMid:23745379

15. Widiasih R, Emaliyawati E, Hendrawati S, Susanti RD, Sutini T, Sari SW, et al. Nurses' actions to protect their families from COVID-19: A descriptive qualitative study. Glob Qual Nurs Res. 2021;8:23333936211014852. https://doi. org/10.1177/23333936211014851

16. Lavadenz Mantilla F. Non-government organizations and local health systems. Bol Oficina Sanit Panam. 1990;109(5-6):5-65. PMid:2151162

17. Lencucha R, Kothari A, Labonte R. The role of non-governmental organizations in global health diplomacy: Negotiating the framework convention on tobacco control. Health Policy Plan. 2011;26(5):405-12. https://doi.org/10.1093/heapol/czq072.

18. Mulvale G, Chodos H, Bartram M, MacKinnon MP, Abud M. Engaging civil society through deliberative dialogue to create the first mental health strategy for canada: Changing directions, changing lives. Soc Sci Med. 2014;123:262-8. https://doi. org/10.1016/j.socscimed.2014.07.029

PMid:25147056

19. Wood L, Shilton T, Dimer L, Smith J, Leahy T. Beyond the rhetoric: How can non-government organisations contribute to reducing health disparities for Aboriginal and Torres Strait Islander people? Aust J Prim Health. 2011;17(4):384. https:// doi.org/10.1071/py11057

20. Kim D. International nongovernmental organizations and the global diffusion of national human rights institutions. Int Organ. 2013;67(3):505-39. https://doi.org/10.1017/ s0020818313000131

21. Hassell TA, Hutton MT, Barnett DB. Civil society promoting government accountability for health equity in the Caribbean: The healthy caribbean coalition. Rev Panam Salud Publica. 2020;44:e79. https://doi.org/10.26633/rpsp.2020.79

PMid:33088289 